\title{
Doing less with less
}

Future historians of Britain and of the NHS may look back on mid-summer 2016 as a pregnant pause, with post-referendum events awaited but not yet arrived. But now we have a new prime minister and, shortly, will have a new financial statement reflecting the reality of the exchange rate and current account deficit. However, quite irrespective of the changing scene and the new realities of the UK's political and financial position in the world, the NHS already faces a tripling of its aggregate deficit to approximately $\mathfrak{£} 1.85$ billion in 2015-16; and, as the King's Fund briefing baldly states, 'the principal cause of the deficit is the fact that funding has not kept pace with the increasing demand for services'. ${ }^{1}$

Before the referendum, the line of argument pursued by many commentators, including the Royal College of Physicians, was simply that the NHS is underfunded and the government should increase the sum allocated to health. The proportion of our gross domestic product devoted to health, even when recently re-stated at about $7.9 \%$ by the government, supplemented by about $2 \%$ private funding, ${ }^{2}$ notoriously compares unfavourably with those countries it is most straightforward to gauge ourselves against, such as France, Germany and the Netherlands - although, the NHS has much to be proud of in the services it provides with this parsimonious distribution. It would be strikingly optimistic in the short term to envisage an economy capable of financing such uplift, or an immediate cash injection into the NHS adequate to deal with its current financial challenge.

The NHS's deficit budgeting cannot be indefinitely prolonged. Yet there is already an undeniably increasing demand for services, based simply on the demography of an ageing population. Already, access to high-quality healthcare in the UK is limited by a number of factors, such as deflection of responsibility between providers, delays in access and denial of some services in a continuing postcode lottery between commissioners. ${ }^{3}$ The clearly desirable aim of correcting these inequities would drive the growth of the deficit further.

So, where do we turn? The options, easy to state, are improving productivity, restricting access to services, or diluting the quality of services. ${ }^{3}$ The latter, unfortunately, is already with us. The King's Fund report highlights issues that those working in the acute sector may be relatively unaware of. Mental health and community budgets have remained in surplus over the last 3 years but at a cost in quality; mental health services have been reconfigured with significant staffing reductions in ways which appear to ignore evidence and poorquality care is 'widespread'. In the community, there has been a shedding of a large number of staff (eg $30 \%$ of senior district nurses), ${ }^{5}$ which is clearly inappropriate as the mantra of shared care between primary and secondary providers in pursued. The acute care sector, which has recently seen welcome increases in nursing establishments following the report on Mid-Staffordshire, is clearly at risk of similar changes, with the obvious risk of a reduction in quality of care.

Of the other options - improving productivity and restricting access - doing more smarter is obviously essential but unlikely to reverse the deficit on its own in the near future. The productivity increase by NHS providers over the last 6 years has averaged $0.1 \%$ (although many would argue that in fact this depressing statement ignores an improvement in the quality of each consultation or transaction) and last year saw a striking fall in the savings achieved through the Quality, Innovation, Productivity and Prevention (QIPP) programme; ${ }^{6}$ so the unwelcome alternative of restricting access to services (politespeak for rationing) looms closer.

It remains surprising that there is no nationwide list of services that NHS patients are entitled to, despite the huge output of the National Institute for Health and Care Excellence (NICE) in providing guidelines for treatment, as well as a huge list of 'donot-do's. However, it is also true that the NHS atlas of variation, on the provision of different service in different parts of England, often flags up treatments that are being under-used rather than over-used. With an eye to the near future, it would seem sensible that colleges and specialist societies should position themselves for the debate in this area by a detailed identification of areas where real savings could be made, on a nationwide basis, at the least cost to quality. Similarly, of course, it remains sensible that relatively evidence-free innovations (some aspects of 7-day working perhaps?) should not be introduced into the NHS without a full assessment of the costs, including the opportunity costs.
Members of the editorial board

Prof Humphrey Hodgson

Editor-in-chief

Dr Paul Grant

Editorial registrar
Cono Ariti

Statistical editor

Nick Cork

Medical student representative
Dr Na'eem Ahmed

Paul Belcher

Dr Rodger Charlton

Dr Tahseen Chowdhury

Dr Kate Evans

Prof Brian Hurwitz

Prof Philip MacCarthy

Prof Martin McKee
Dr Mehool Patel

Dr Gerrard Phillips

Dr Roby Rakhit

Prof Philip Smith

Dr Angela Star

Dr Kevin Stewart

Prof Cameron Swift 


\section{References}

1 Dunn P, McKenna H, Murray R. Deficits in the NHS 2016. London: The King's Fund, 2016.

2 Appleby J. Is the UK spending more than we thought on health care (and much less on social care)? London: The King's Fund, 2016. Available online at www.kingsfund.org.uk/blog/2016/06/uk-spending-health-careand-social-care [Accessed 13 July 2016].

3 Robertson R. Six ways in which NHS financial pressures can affect patient care. London: The King's Fund, 2016. Available online at www.kingsfund. org.uk/publications/articles/six-ways [Accessed 13 July 2016].
4 Gilburt H. Mental health under pressure. London: The King's Fund, 2015. Available online at www.kingsfund.org.uk/publications/ mental-health-under-pressure [Accessed 13 July 2016].

5 Foot C, Sonola A, Bennett L et al. Managing quality in community health services. London: The King's Fund, 2014.

6 Lafond S, Charlesworth A, Roberts A. A perfect storm: an impossible climate for NHS providers' finances? London: The Health Foundation, 2016.

Humphrey Hodgson

\section{Royal College} of Physicians

\section{Physicians and war}

\section{War has been a frequent feature of British life over the 500 years of the Royal College of Physicians' existence, and has an important place in the histories of both the RCP and medicine.}

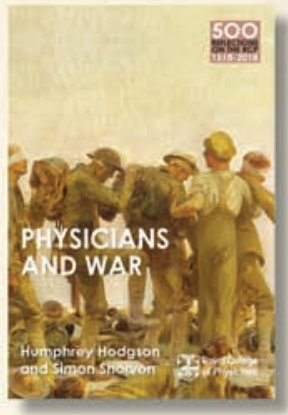

Order by phone or online

$\mathrm{Tel}+44(0) 2030751358$

or visit www.rcplondon.ac.uk/shop
Price: $€ 12$

(Postage and packaging not included)

$10 \%$ discount for fellows and members.

$15 \%$ discount for foundation doctors and students 